\title{
＜合同シンポジウムI >
}

\section{超急性期局所線溶療法の現状}

\section{—MELT Japan study から}

井上敬 小笠原邦昭 小川 彰

MELT Japan study group, 岩手医科大学脳神経外科

要旨：本研究は MELT Japan study として厚生労働科研費の補助を受け，平成 13 年度より 開始された。発症 6 時間以内の中大脳動脈閉塞症を対象とし, UK 群, 治療群の 2 群に割り付け た. UK 群はウロキナーゼ局所投与を施行され，対照群には線溶療法以外の治療を行った. エン ドポイントは 3 カ月後の modified Rankin scale (mRS) で評価した。平成 17 年 10 月時点で 115 例が登録され 105 例の中間解析結果を行った。死亡率・有害出血性変化は両群に有意差を認め なかった. mRS 2 以下の症例はUK 群，対照群で有意差を認めなかった. mRS 1 以下の症例は UK 群 53 例中 22 例，対照群 52 例中 11 例と有意に UK 群に転㷌良好例が多かった $(p=0.034)$. 平成 18 年 1 月までに最終結果が報告される予定である.

Key words : ウロキナーゼ, 局所線溶療法, 中大脳動脈閉塞症

(脳卒中 $27: 487-491,2005$ )

\section{はじめに}

脳梗塞急性期経静脈的線溶潦法は米国では既に確立 された治療である1”。本邦でも平成 17 年 10 月 11 日ア ルテプラーゼが薬事承認された。 しかし静脈内投与法 では一部の症例では有効であることが大規模比較試験 で示されているが，同時に致死的合併症の発生も報告 されている ${ }^{1)}$ さらに有効とされるのは発症からわず か 3 時間以内の症例に限られており, 医療用へリコプ ター等の整備が遅れている我が国の実情では, 適応と なるのはごく一部の症例になるだろうと矁念されてい る.

一方, 経動脈的線溶療法は経静脈的投与に比べより 効果的である可能性が示唆されているものの, 未だ大 規模ランダム化試験等の質の高いエビデンスは存在し ていない，そこで超急性期局所線溶療法多施設共同試 験 (MCA-Embolizm Local Fibrinolytic Intervention Trial Japan : MELT Japan Study) がウロキナーゼを用 い，急性期局所線溶療法の有效性を評価する事を目的 に平成 13 年度より開始された。本研究の目的は, 経動 脈的線溶療法有効性を大規模ランダム化試験によって 確認し, 脳梗塞患者転㷌を改善せしめ, さらに家庭ま
たは社会復帰率を高めることである。

\section{方法}

対象

20 歳以上 75 歳以下で, CT では全く変化を認めない か軽度の初期虚血変化のみの, 発症 6 時間以内の中大 脳動脈閉塞症を対象とした。選択基準を表 1 に示した。 割付

セキュリティーを確保したインターネット上にアロ ケーションセンターを設置し，急性期割付を行いUK 群と対照群の 2 群に振り分けた. UK 群はウロキナー ゼ動注を行い, 対照群は局所線溶療法（動注, 静注ど ちらも）以外の一般的治療を行うこととした。

エンドポイント

1 次エンドポイントは発症 3 カ月での modified Rankin Scale (mRS) 0-2 を転州良好群とした. 2次エ ンドポイントは mRS 0, 1 の症例を転帰良好群とし た.

\section{インターネット上での割付}

大学医療情報ネットワーク (UMIN) の協力の下，暗 号通信システムによるインターネットを用いた割付を 行った。研究者は事前に登録し，独自の ID およびパス 
ワードが付与され，これを用いることにより，24時間 症例の登録, 割付を可能とした（http://melt.umin.ac. $\mathrm{jp} /$ ). 実際の登録方法は, 血管撮影以外の選択基準を満 たし，除外基準のいずれにも該当しない対象候補患者 があった場合直ちに患者のイニシャルと生年月日を もって pre-registration を行うこととした. 続いて血管 撮影を行い，血管撮影の条件に合致し，インフォーム ドコンセントが得られた時点で, registration を行い治 療群の割付を得ることとした，治療群の割付は，対象 例を無作為にNIHSS，年齢，施設に関して最小化法で 2 群の平衡をとりながら行った。

CT 撮像法・読影法の標準化および適応基準

CTでの適応基準はCT でまったく変化を認めない 加，病側に軽微な初期虚血変化（島皮質, 前頭・側頭 弁蓋部に限局する吸収値のわずかな低下やシルビウス

表 1 適応基準

（1）血管撮影で急性中大脳動脈閉塞

(2) 発症時刻が特定可能で発症後 6 時間以内

（3）CTでまったく変化を認めないか，病側に軽 微な初期虚血変化のみを認めるもの

（4） CT 撮影後より 2 時間以内に局所線溶療法を 開始できる患者.

（5）年歯令 20 歳以上， 75 藏以下
裂の消失，レンズ核の不鮮明化）のみを認めるもの， ただしCT 撮影後より 2 時間以内に局所線溶療法を開 始できる患者とした。

$\mathrm{CT}$ 撮像条件を裴 2 に示す，各施設に上記条件にて 実際に撮像したフィルムを画像判定中央委員会に送付 してもらい，十分な画像が得られているか否かを症例 登録に先立って検討した。

インターネット上で実際の症例を用いた読影練習が できるシスデムを構筑し（https://endai.umin.ac.jp/ islet/melt/ct/ct_gl01.htm)，登録者であればいつでも 練習可能なようにした，CTによる適応基準を表 3 お よび図1に示す。

\section{結果}

インターネットを利用した 24 時間登録・割付シス テムでは， 4 年間に 1 度システムメンテナンス中に登 録できないことがあったが，それ以外は特にトラブル なく割付が行えた。平成 17 年 10 月 11 日アルテプラー ゼの急性期脳梗塞に対する経静脈的投与法が薬事承認 されたのをうけ，一旦症例登録が中止された，その時 点で 115 例が登録され，105例が 3 力月間の経過観察 を終了しており中間解析が行われた。

105 例の中間解析結果では, 死亡率・有害出血性変 化に関してUK 群・対照群に有意差を認めなかった。

表 2 術前判定基準における初期虚血変化の判定

1）スキャン方式は装置の世代に関わらずコンベンショナルスキャンとする（ヘリカルスキャンは不可）。

2）スライス厚は原則としてテント上は 8-10mm 厚とする.

3）再構成関数（フィルタ）は最適のものを選択する（頭部用に特に用意されていない場合はstandardで可）.

4）CRT上での観察，フィルムへの焼き付けは十分狭いWindow 幅で行う (Window 幅 80 以下を推奖).

5）管電圧，管電流，回転速度はメーカ，機種によって状況が大きく異なるので，推奨条件の設定は行わなかっ たがただし，回転速度 (スキャン時間) は最新機種であっても 180 度/秒以下 (2 秒/回転以上)が望まし いとした。一般に管電圧，管電流は高いほど，回転速度は遅いほどコントラスト分解能は高くなり同時に患 者被曝，X線管球の発熱/負荷も增大することをふまえ，各装置ごとに最適の条件で撮像するよう心がける ものとした。

MELTJapan ウェプページ（https://endai.umin.ac.jp/islet/melt/ct/ct_gl01.htm）より許可を得て転載

表 3 術前判定基準における初期虚血変化の判定

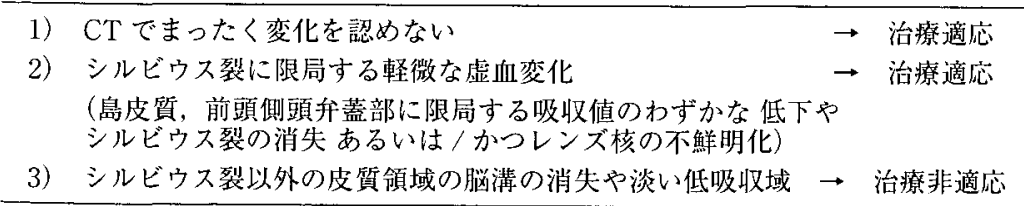

MELTJapanウェブページ（https://endai.umin.ac.jp/islet/melt/ct/ct_gl01.htm） より許可を得て転載 

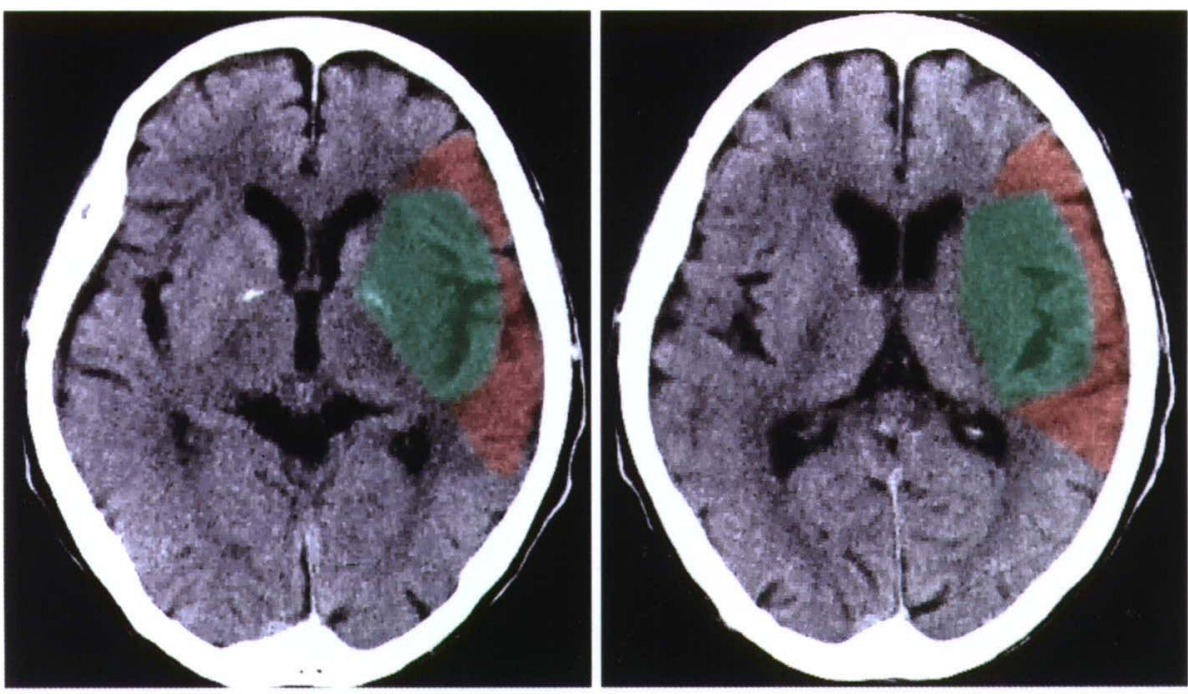

MELTJapanウェブページ(https://endai.umin.ac.jp/islet/melt/ct/ct_gl01.htm) より許可を得て転載

图 1

初期虚血変化が緑の領域のみに限定している場合は，治療適応あり． 赤の領域に及んでいる場合は, 治療非適応とした.

$\mathrm{mRS}$ の分布
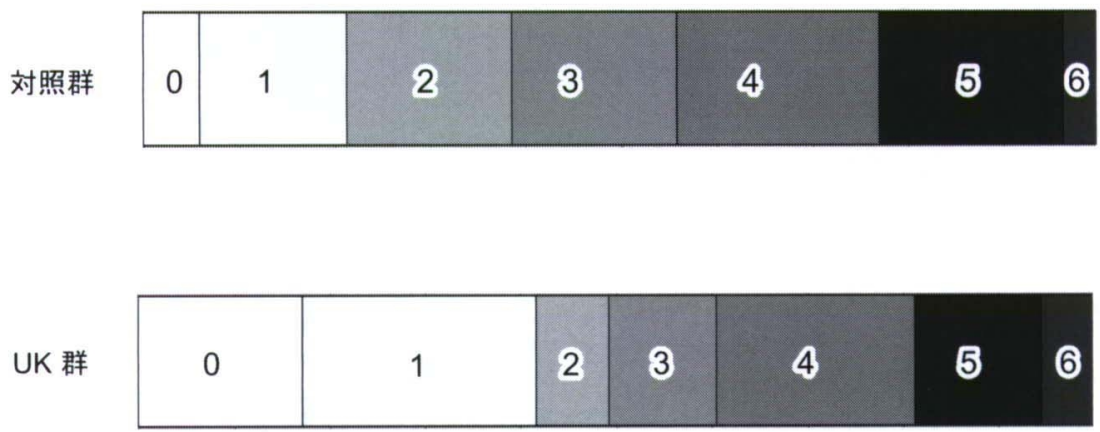

図 2

対照群および UK 群の 3 カ月後の modified Rankin Scale（mRS）の分布を示す. UK 群において有意に mRS 0, 1 の症例が多い $(\mathrm{p}<0.034)$.

1 次エンドポイントとした mRS 2 以下の症例はUK 群 53 例中 26 例, 対照群 52 例中 20 例と有意差を認め なかった. 2 次エンドポイントとした mRS 1 以下の症 例は UK 群 53 例中 22 例, 対照群 52 例中 11 例と有意 にUK 群に転帰良好例が多かった $(\mathrm{p}=0.034)$ (図 2).

\section{考察}

平成 17 年 10 月 11 日現在で登録症例は 115 例で あった。これは目標症例の 200 例の $1 / 2$ 強であった. 症例数が予想以下であったことから平成 15 年 9 月に 参加施設を対象に過去 2 年間の脳塞栓症症例をリス卜 アップしたが，その結果予想以上に高齢者が多く，年 
齢による条件を満たさず，適応外とされた症例が多い ことが判明した。また，発症数時間で来院した症例に おいても, 本研究のCT 撮像条件, 読影法を使用した場 合適応外となる初期虚血変化が見られることもわかっ た，症例数が予想を下回っている理由は上記 2 点が考 えられた。

インターネットを利用した 24 時間登録・割付シス テムは重大な問題点なく運用できた，ただし，脳血管 撮影空にインターネットアクセス可能なコンピュータ がなく，医局等の別室から実際療法を行っている医師 に電話で連絡を取りつつ, 割付を行った等の報告が あった．本研究のようにリアルタイムで症例の登録, 割付を行う必要がある疾患の場合，七キュリティーの 問題さえクリアすれば，インターネットを用いる手法 は有効であることが確認された。

MELT Japan では画像による適応症例の判断に, CTのみを用いた。これに関しては, 研究開始当初様々 な意見が存在した. MRI 拡散強調画像, SPECT 等によ る脳血流画像の必要性も考慮されたが，最終的に装置 が普及していること，24 時間使用可能なこと，発症か ら 6 時間以内に治療を開始しなくてはならないことか ら CTのみを必須の検查とするに至った.ただし, 初期 虚血変化を鋭敏に描出するために特化した条件での撮 像を義務づけたことにより, 出血性合併症の頻度も予 想範囲内に収まった、ヘリカルスキャンを不可とした が，こ机はへリカルスキャンでは初期虚血変化を判定 するに十分な信号雑音比を得るのが困難と判断された ためであった．実際の条件は $250 \mathrm{~mA} ， 2$ 秒スキャン以 上の条件にて，比較的良好な信号雑音比を得ることが できた．CTにおけりる初期虚血変化の判定は決して平 易ではなく，判定医は判定規準を十分に理解するとと もに，所見判定に十分習熟している必要がある。判定 の䛊りは重大なプロトコール違反に直結し，本試験の 質の低下に慗がる，との認識の元，読影法の標準化を 行った．実際これまで，プロトコール違反率が高いと 症侯性頭蓋内出血が多いことや死亡率が上昇すること が報告されている233.

未だ中間解析の段階ではあるが, 本研究の結果, 局
所線溶療法が 6 時間以内の症例において社会復㷌率を 有意に改善することが示された。アルテプラーゼ静脈 投与の対象になるのは全脳梗塞症例の数\%にすぎない とも報告されている ${ }^{3)}$. 発症 3 時間以内に治療を開始 するためには実際には発症 2 時間以内に来院していな いと困難である。このことが対象症例が少ないことの 原因の一つと考えられる，局所線溶療法では発症 6 時 間まで患者転帰を改善することが示された。このこと はより多くの症例の転帰を改善できる可能性を示すも のと考えられた。

本邦でのアルテプラーゼ適応拡大を受け，本研究は 一旦登録を中止した。これは，プロトコール上対照群 に線溶潦法を行わないこととなっていたため，現状の プロトコールでは, 対照群が存在しなくなるためで あった。そこで，現在プロトコール改訂委員会を立ち 上げ，新プロトコールを作成している段階である．平 成 17 年 12 月までに新プロトコールを作成し，周知期 間をおいた後, 平成 18 年 4 月からは新プロトコールの もと登録を再開する予定である。

\section{結 語}

中間解析において局所線溶療法の有効性が示唆され た.平成 18 年 1 月までに最終結果が報告される予定で ある。

\section{文献}

1) Tissue plasminogen activator for acute ischemic stroke. The national institute of neurological disorders and stroke rt-pa stroke study group. $\mathrm{N}$ Engl J Med. $1995 ; 333$ : 1581-1587

2) Graham GD. Tissue plasminogen activator for acute ischemic stroke in clinical practice: A metaanalysis of safety data. Stroke. $2003 ; 34: 2847$ 2850

3) Katzan IL. Furlan AJ, Lloyd LE, Frank JI, Harper DL, Hinchey JA, Hammel JP, Qu A, Sila CA. Use of tissue-type plasminogen activator for acute ischemic stroke: The cleveland area experience. Jama. $2000 ; 283: 1151-1158$ 


\section{Abstract \\ Local fibrinolysis for acute ischemic stroke in MELT Japan Study}

Takashi Inoue, M.D., Kuniaki Ogasawara, M.D. and Akira Ogawa, M.D.

MELT Japan Study Group.

Department of Neurosurgery, Iwate Medical University School of Medicine

We report the results of MELT Japan Study. This study was supported by Grants-in-Aid of the Ministry of Health, Welfare, and Labor, Japan. The patients with acute M1 or M2 occlusion within 6 hours from onset were included. They were randomized to the group that was treated using intra-arterial injection of urokinase (UK group) and to the group that was treated conservatively (Control group). The end point was defined the modified Rankin scale at three month. There are 115 registrations at October 2005 . No difference is observed in the ratio of critical hemorrhagic transformation between two groups. The percentages of good outcome were $41.5 \%$ in UK group and $21.2 \%$ in Control group ( $\mathrm{p}<0.034)$. MELT Japan has possibility to produce new knowledge in the treatment of the acute cerebral embolism though it progresses at present.

(Jpn J Stroke $27: 487-491,2005$ )

Key words : local fibrinolysis, middle cerebral embolism, urokinase 